\title{
BIOGRAFI K.H AHMAD ZUHDIANNOOR
}

\author{
Yusup \\ Email : $2010128210007 @$ mhs.ulm.ac.id \\ Program Studi Pendidikan IPS Fakultas Keguruan dan Ilmu Pendidikan \\ Universitas Lambung Mangkurat \\ Banjarmasin
}

\begin{abstract}
Negara Indonesia memiliki berbagai wilayah dari sabang sampai marauke. Setiap wilayah yang ada di Indonesia memiliki suatu Provinsi, salah satunya ialah Provinsi Kalimantan Selatan yang memiliki berbanyak para Ulama yang terkenal di kalangan masyarakat. Ulama sendiri ialah orang yang takwa kepada Allah SWT, berilmu agama sangat baik yang memberi bimbingan terhadap kalangan masyarakat kejalan kebaikan. Alhamdulillah di Provinsi Kalimantan memiliki banyak para Ulama yang menjadi suatu pengaruh sangat baik bagi kehidupan. Salah Satu Ulama yang ada di Kalimantan Selatan ialah K.H. Ahmad Zuhdiannoor yang sangat pengaruh besar terhadap kalannagan masyarakat menjadi lebih baik dengan adanya syukur dan sabar.

\section{PENDAHULUAN}

Indonesia adalah suatu negara yang maritim yang memiliki beribu-ribu pulai dengan wilayah teritorial laut yang sangatlah luas dan juga memiliki daratan serta laut sangat luas yang membentang sepanjang Khatulistiwa dan memiliki letak dianatar Benua Asia dan Australia. Dengan hal itu lah menunjukan adanya 5 pulau terbesar dan ratusan pulau kecil yang di huni/ tidak oleh mahluk hidup. ( Winarti, R, 2015 ).

Kalimantan Selatan meruapakan suatu Provinsi yang memiliki suatu suku bangsa, salah satunya ialah suku banjar yang beragama islam dengan berdasarkan sebuah data berdasarkan jumlah pemeluk Agama Islam di Kalimantan Selatan mencapai lebih dari 97\% persen sebab dari adanya sebuah dakwah yang disampaikan dari berbagai tokoh Agama Islam yang sering disebut Ulama, akibatnya Ulama memiliki suatu kedudukan yang sangat penting dalam sebuah kehidupan masyarakat banjar dari waktu ke waktu. ( Septiady, E. (2021).
\end{abstract}


Ulama ialah sosok terkemuka di kalangan masyarakat sebab memiliki kompentensi dalam bidang keagamaan sangat tinggi di dalam masyarakat dan sebagai pemimpin dari agama serta berperan dalam memimpin dari sosial agar dapat di kendalikan terhadap individu dan kelompok. ( Amrullah, M. K, 2020 ).

\section{BIOGRAFI}

K.H Ahmad Zuhdiannoor ( 1972-2020 ) yang terkenal dengan nama Guru Zuhdi lahir di Alabio, Hulu Sungai Tengah, lahir pada 10 Febuari 1972. K.H Ahmad Zuhdiannoor meruapakan anak dari pasangan K.H. Muhammad bin Jafri dan Hj.Zahidah Binti K.H. Asli. Guru Zuhdi memiliki 8 saudara dan saudari yakni Hj. Naqiah, Sa'aduddin, Jahratul Mahbubah, As'aduddin, Zulkifli, Najiah, Nashihah, dan Nafisah. Guru Zuhdi sangat arab dikenal dengan sebutan Abah Haji juga di kalangan masyakat banjarmasin. Guru Zuhdi memiliki Ayahanda dan kakeknya yang memiliki peranan sebagai ulama dikalangan masyarkat. Ayahanda Guru Zuhdi pernah menjadi bagian dari Pondok Pesantren Daussalam Martapura dan pernah menjadi Pemimpin di Pesantren Al-Falah sebab Meninggalnya K.H Muhammad Sani pada saat pemimpin sebelumnya. Sedagkan kakeknya memiliki peranan ulama yang berada daerah Alabio. Hal inilah menjadikan Guru Zuhdi sebagai Penerus Kakek serta Ayahandanya. Dimulai dari Pendidikan Guru Zuhdi ialah sampai tingkatan Sekolah Dasar (SD) akan tetapi beliau juga melanjutkan Pondok Pesantren Al-Falah Yang terletak di Banjarbaru dalam kurun waktu kira-kira 2 bulanan disebabkan oleh kondisi tidak memungkinkan akibat sakit yang sering terjadi. Hal itu menjadikan Guru Zuhdi di bimbing oleh Kakeknya sendiri dalam mempelajari Ilmunya yang bertempat di Alabio oleh Ayahandanya.

Setelah waktu terus berjalan kakek dari Guru zuhdi meninggal sehingga beliau pulang ke Banjarmasin yang mana akan didik oleh ayahandanya sendiri serta ia belajar juga dengan Guru yang berada di Teluk Tiram yang bernama K.H.Abddus Syukur. Seberapa waktu berjalan K.H. Abdus Syukur juga meninggal sehinga beliau di antar oleh Ayahandanya kepada Guru Sekumpul atau Guru Zaini yang sering dipanggil Guru Ijai dikalangan masyarakat sekitar 7 tahunan belajar. Jadi Guru Zuhdi selalu belajar dimana pun dan kepada siapapun sebab adanya peranan sang ayahanda dan kemauan dirinya sendiri. Ilmu Guru Zuhdi yang didapat dari awal ialah Ilmu Tauhid, Tasawuf, Fikih, Arudh, Usul Fiqih. Dan Guru zuhdi dalam bidang Ilmu Tauhid mengkaji sebauh 
kitab Syarh Hudhudi karya Abdullah AL-Hijazi al-Syarqawi dan sebagainya, sedagkan bidang ilmu Fiqih yakni syarah sittin karya Abu Al-Abbbas Ahmad Al Anshari dan sebagainya.

Alhamdulillah Guru Zuhdi menjadi pengajar di Pesantren Al-falah sebab ilmu yang sudah dipelajari sudah sangat cukup akibatnya beliau menjadi bagaian dari Pesantren tersebut sekitar 2 tahuanan. Tidak lama beliau membuka Majelis Agama di Banjarmasin, Kalimantan selatan. Bertempat di Langgar Darul Imam di sebauh Komplek Pondok Indah Teluk Dalam, Mesjdi Sabilal Muhtadin Banjarmasin, Mesjid Jami Sungai Jingah Banjarmasin. Waktu pengajian hari Kamis, Jum'at, Sabtu dan Ahad masing-masing diadakan ketika waktu malam yang mana sering ketika sesudah sholat magrib atau Isya selesai. Dengan para Jamaah pria dan perempuan sesuai ketentuan ketika pengajian. Semua kalangan Mayarakat sangat lah bersemangat dalam pengajian beliau sebab dalam yang beliau sampaikan berkenanan dengan suatu kehidupan masyakat sekitar menjadi kan yang awalnya tidak tau menjadi tau dengan yang gaya beliau yang sangat disenangi masyakarakat, sangat membimbingan ke arah lebih baik dan meningkatan ketakwaan terhadap Allah SWT. Ketika pengajian beliau sampaikan adanya peranan media dalam menjadikan suatu dokumentasi dari setiap kali beliau sampaikan yakni di rekam melalui Smartphone dan sebagainya yang mana nanttinya akan di uploud di berbagai sosial media agar tidak ketinggalan apa saja dari pengajian beliau seperti sosial media Youtube, Instragam, Whatsaab dan sebagainya.

Sebagai Ulama Guru Zuhdi sangat lah memberikan sesuatu di penyampaian ceramahnya itu memasukan nilai nilai pendidikan terhadap masyarakat agar setiap menjalani suatu kehidupan pegang lah syukur dan sabar sebab dengan sesorang yang dapat mengamalkan syukur dan sabar maka dalam kehidupannya akan tenang karena ketika diberi sebuah cobaan akan tetap bersyukur, misalnya seorang yang berkerja hari mendapatkan sebuah uang Rp. 20.000 dari usaha menjadi seharian maka perlu bersyukur atas apa yang telah didapatkan sebab jika tidak memiliki syukur maka seorang itu pastinya selalu menyalahkan orang diskitarnya dengan tidak kekaruan akibatnya menjadikan sesuatu hal hal tidak di inginkan terhadap dirinya maupun orang lain. Ketika bersabar yakni ketika sesorang tertimpa sebuah musibah yang menghanguskan rumah mereka maka ketika seorang itu memiki sifat sabar maka menerima apa yang sudah terjadi tidak menyalahkkan ini dan itu yang menjadi penyebabkan kebakaran yang terjadi yang menimpa mereka sebab ketika bersabar maka percayalah ada hikmah yang sangat baik akibatnya seorang itu tertanam selalu berpikir positf dan menerima apapun yang telah terjadi. 
Peranan Guru zuhdi sebagai salah satu yang termasuk dalam Pemadam Kebakaran (BPK) Majelis Taklim (Majta) menjadi anggota bernomor 1 dengan memakai atribut lengkap seperti para relawan biasanya pakai. yang sangat membantu ketika ada musibah kebakaran yang terjadi di wilayah Banjarmasin. Peranan Guru Zuhdi juga sebagai relawan ketika Haul Guru Sekumpul di Martapura sebagai relawan yang memberikan suatu tenaga dalam melayani masyarakat ketika acara hualan dengan adanya masyarakat kenal dan tidaknya terhadap beliau sebab beliau sangat terkenal sebagai ulama di banjarmasin akibatnya tidak akan heran jika ketemu sidin pastinya sangat tau.

Guru Zuhdi memberikan pendapatnya berkenanan dengan Persebaran Virus Corona terjadi di Indonesia terutama yang berada di kalimatan selatan yang mendomilisi Banjarmasin. Beliau memberikan suatu pandadangan terhadap masyarakat agar bersabar dalam musibah adanya persebaran Virus Corona akan tetapi beliau memberikan sesuatu kepada masyakat agar selalu sabar dan syukur setiap apapun yang terjadi sebab akan ada nantinya Hikmah yang dapat diambil dan beliau menyampaikan kepada masyarakat untuk mengikuti pemerintah yang selalu memberikan sesuatu kebijakaan sosial yang akan keamanan dan kedamianan yakni menaati protokol kesehatan yang nantinya akan menjadi suatu hasil ketika adanya penyebaran Virus Corona dapat terselesaikan dengan sebaik baiknya dari dukungan beliau juga acara pengajian yang selalu terjadwal menjadi tidak di lakukan seperti biasanya.

K.H. Ahmad Zuhdiannor wafat pada Hari Sabtu, 2 Mei 2020, Di Suatu Rumah Sakit Medistra di Jakarta. Kabar dari Anggota DPR RI Dapil Kalsel Syaifulllah Tamliha dari Dr.Gunawan SPD, yang menjadi penangan beliau ketika itu yakni Guru Zuhdi dengan pesan tertulis "Izin mengabarkan berita duku, Guru Zuhdi meninggal pagi ini dengan gagal nafas dan gagal jantung, manusia berusaha Tuhan yang berkendak. Mohon maaf untuk semua kekurangan selama merawat beliau". Dari kalangan masyarakat sangat lah berduka ketika itu sebab Guru Zuhdi yang sangat dikenal memiliki keistimewaan tersendiri terhadap masyarakat akibatnya ketika itu para kalangan masyarakat menunggu kedatangan jenazah beliau di sekitaran Mesjid Jami Sungai Jinggah Banjarmasin dengan adanya kawalan polisi dan sebagainya agar tidak terjadi kerumunan yang tidak diinginkan sebab masih dalam keadaan penyebaran Virus Corona saat itu akibatnya kalangan masyarakat juga mematuhi sesuai dengan ketentuan yang diberitahukan. 
Wasiat Guru Zuhdi sampaikan terhadap masyarakat ialah syukur dan sabar. Dalam kehidupan penuh lah bermacam cobaan yang silih berganti sebab perkembangan zaman yang selalu terjadi akibatnya mau tak mau, siap tak siap pastinya akan terjalani dengan perubahan yang akan terjadi maka perlu lah syukur dan sabar sebab dengan adanya syukur, setiap individu tidak akan merasa kekurangan dan dengan adanya sabar selalu menerima dengan ikhlas apa yang sudah terjadi akibatnya individu tersebut sangat berkualitas dalam kehidupannya yang tidak akan merasa ada beban dalam kehidupannya.

\section{METODE}

Lokasi adalah Kalimantan selatan, wilayah Banjarmasin di kalangan masyarakat dekat dengan Mesjid Jami Sungai Jingah Banjarmasin. Metode sejarah ini melalui empat tahapan untuk mendapat hasil yang diinginkan yakni hauristik, verifikasi/kritik, interprestasi, dan historiografi. Dengan mengumpulkan sumber, data, dan jejak sejarah, dengan cara mengkritik terhadap sumber yang didapatkan sumber yang sangat akurat dan terbukti dengan melalui 2 tahapan kritik ekstern dan intern, serta adanya usaha untuk menjadikan sumber itu menjadi satu kesatuan yang tersusun dengan sebaiknya sesuai dengan keadaanya dan terakhir ialah dalam bentuk tulisan agar dapat menjadi hasil yang masih ada untuk menjadi suatu hasil bersama-sama mengenai K.H. Ahmad Zuhdiannor sebagai ulama di kalangan masyarakat banjar.

\section{SIMPULAN}

K.H. Ahmad Zuhdiannor adalah ulama agama islam yang berada di Kalimantan Selatan berada di Banjarmasin, Beliau menempuh Pendidikan Dasar yakni tingkatan SD dan dilanjutkan di Pondok Pesantren Al-Falah, Di didik oleh kakeknya dan Ayahandanya sampai berguru dengan Guru sekumpul di Martapura serta berguru K.H.Abddus Syukur di Teluk Tiram dan sebagainya. Ilmu Guru Zuhdi yang didapat dari awal ialah Ilmu Tauhid, Tasawuf, Fikih, Arudh, Usul Fiqih. Dan Guru zuhdi dalam bidang Ilmu Tauhid mengkaji sebauh kitab Syarh Hudhudi karya Abdullah AL-Hijazi al-Syarqawi dan sebagainya, sedagkan bidang ilmu Fiqih yakni syarah sittin karya Abu

Al-Abbbas Ahmad Al Anshari dan sebagainya hingga menjadi pengajar di Pesantren Al-falah di lanjutkan membuka Majelis Agama di Banjarmasin, Kalimantan selatan. Bertempat di Langgar Darul Imam di sebauh Komplek Pondok Indah Teluk Dalam, Mesjdi Sabilal Muhtadin Banjarmasin, Mesjid Jami Sungai Jingah Banjarmasin. Dengan Waktu pengajian hari Kamis, Jum'at, Sabtu dan Ahad masing-masing diadakan ketika waktu malam yang mana sering ketika 
sesudah sholat magrib atau Isya selesai. Dengan para Jamaah pria dan perempuan sesuai ketentuan ketika pengajian. Semua kalangan Mayarakat yakni dari anak kecil, remaja, orang tua dan para pemimpin dan sebagainya ikut juga dalam pengajiannya sebab pembelajaran yang beliau sampai berkenanan mengenai kehidupan masyarakat dari perkembangan jaman hingga hulu hara yang terjadi ditengah masyarakat yang menjadi permasalahan dengan adanya penekanan beliau mnegani kehidupan yakni syukur dan sabar dalam kehidupan akibatnya individu dan kelompok iu tidak merasa khawatir lagi dengan segara macam hal hal yang keduniaan.

\section{REPERENSI}

Abbas, E. W. (2015). Guru Sekumpul: Bacaan Pengantar. Penerbit Wahana Jaya Abadi.

Amrullah, M. K. (2020). The South Kalimantan Ulama's Leadership in Covid-19 Pandemic Era. INNOVATIO: Journal for Religious Innovation Studies, 20(2), 111-124.

Andy Pribadi, (2020). Kabar duka meninggal Guru Zuhdi.

Dedi G sanusi, (2018). Guru Zuhdi ikut memadamkan api.

Handy, M. R. N., \& Fatimah, S. N. (2019). Biography of Syekh Muhammad Nafis Al-Banjari: An Investigation of Value in the Spread of Islam as a Learning Source on Social Studies. The Kalimantan Social Studies Journal, 1(1), 40-50.

Helim, A. (2016). Pemikiran hukum ulama Banjar terhadap perkawinan Islam di Kalimantan Selatan (Doctoral dissertation, Fakultas Syariah).

Mujiburrahman, M., \& Abidin, M. Z. (2012). Ulama Banjar Kharismatik Masa Kini di Kalimantan Selatan: Studi terhadap Figur Guru Bachiet, Guru Danau, dan Guru Zuhdi. Al-Banjari: Jurnal Ilmiah Ilmu-Ilmu Keislaman, 11(2).

Najla, A. (2017). PERAN PENGAJIAN TERHADAP PERKEMBANGAN KONSEP KEBERAGAMAAN PADA DIRI REMAJA DI KOTA BANJARMASIN. Al-Hiwar: Jurnal Ilmu dan Teknik Dakwah, 5(10).

Rifansyah, R. (2019). Materi Pendidikan Akhlak Pada Majelis Taklim Guru Zuhdi Banjarmasin.

Septiady, E. (2021). PERKEMBANGAN EKONOMI DI WILAYAH SEKUMPUL MARTAPURA SEBELUM DAN SESUDAH MENINGGAL GURU SEKUMPUL.

Tim MUI Kalsel dan Tim LP2M UIN Antasari Banjarmasin ( 2018 ). ULAMA BANJAR DARI MASA KE MASA. Antasari Press. Jl. A. Yani KM 4,5 Banjarmasin, Kalimantan Selatan. 